\title{
TÁPLÁLKOZÁSI SZOKÁSOK VIZSGÁLATA A DEBRECENI EGYETEMISTÁK KÖRÉBEN
}

\author{
- मी० -
INVESTIGATING THE DIETARY PRACTICE OF STUDENTS AT THE UNIVERSITY OF DEBRECEN

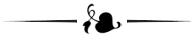 \\ KARNAI, LAURA \\ SZÚCS, ISTVÁN

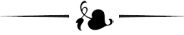 \\ Debreceni Egyetem, Gazdaságtudományi Kar, Gazdálkodástudományi Intézet \\ (University of Debrecen, Faculty of Economics and Business, Institute of Applied Economics Sciences)
H-4032 Debrecen, Böszörményi út 138. \\ e-mail: karnai.laura@econ.unideb.hu
}

\begin{abstract}
Gi
Nowadays, the importance of food in the preservation and restoration of health has become more and more important, as the number of people suffering from diabetes, cardiovascular disease and various food allergies is increasing. In many cases, there is a problem with what is the recommended range of foods, and what is (the meaning of) a healthy and healthconscious diet. The focus of our study is on the nutritional habits of young university students, as the health consciousness of this age group plays a prominent role at both domestic and international level. The primary purpose of the research is to map the daily dietary habits university students in Debrecen to the recommendations of the nutritional pyramid of dietary nutrition and good nutrition created by dietitians. The basis of our primary study was the observational procedure by creating a food diary and fill it with the randomly chosen students, during which we could observe the quality and quantity of food consumed by them during their daily meals. On the basis of the results, the dietitians expected and actual food consumption in the case of the target group were able to compared, on the basis of which it can be concluded that the eating habits of the university students of Debrecen fall short of the healthy eating recommendation.
\end{abstract}

KuLCSSZAVAK: egészségtudatos táplálkozás, fogyasztói szokások, táplálkozási piramis

JEL-Kódok (JEL CODES): A13, P56

DOI: https://doi.org/10.20494/TM/6/2/4

\section{BEVEZETÉS - INTRODUCTION}

Az élelmiszeripar globális jelentősége manapság egyre inkább felértékelődik, köszönhetően a világméretű élelmiszerigény ugrásszerü növekedésének. Világviszonylatban a fogyasztói igények terén is változás figyelhető meg, melyet a civilizációs betegségek rohamos terjedése hívott életre, hiszen nő a cukorbetegséggel, szív- és érrendszeri betegséggel és különböző ételallergiával küzdők száma. Ezt bizonyítja az is, hogy hazánkban a cukorbetegek száma egy
KEYWORDS: healthy diet, consumer behaviour, healthy diet pyramid évtized alatt megduplázódott, s mára már eléri az 1 millió foot, de hasonló tendencia figyelhető meg az ételallergiától és/vagy intoleranciától szenvedők száma tekintetében is (KSH, 2019). Napjainkban egyre inkább előtérbe került az étkezés fontossága az egészség megőrzésében és helyreállításában, hiszen a táplálkozásunk közvetlenül befolyásolja egészségünket (WHO, 2006; POPKIN, 2006). Életmódunk és fogyasztási szokásaink gyermekkorunktól kezdve kihatnak a szervezetünkre, a táplálkozási szokások változása különböző táplálkozási zava- 
rokat idézhet elő, melyek fóként felnőttkorban okoznak problémát, ezért egész életünk során figyelnünk kell arra, hogy mit eszünk és iszunk (MORENO et al., 2014). Ugyanakkor az elfogyasztott étel és az egészség közti szoros összefüggést már időszámításunk előtt is ismerték („Gyógyszered legyen az ételed, s ételed legyen a gyógyszered" -Hippokratész). Az egészségtelen táplálkozás és a mozgásszegény életmód napjainkban a Föld összlakosságát tekintve a legjelentősebb rizikófaktorrá vált, ezért a szakterületi nemzetközi kutatásokban is prioritást élvez (LIM et al., 2012). Mindezen tények új kihívások elé állítják az élelmiszeripart, hiszen olyan élelmiszerek kifejlesztése és gyártása szükséges, melyek egészségvédő hatásuknál fogva lassítják a társadalmat sújtó civilizációs betegségek térnyerését. A boltok polcain ennek köszönhetően nő azon termékek száma, melyek a kiváló élvezeti érték mellett az egészségre jótékony hatással bírnak, mint például az ásványianyag-tartalom növelése (pl. $\mathrm{Mg}, \mathrm{Ca}$ ), az energia csökkentése cukortartalom vagy zsírtartalom csökkentés által, az egészségre jótékony hatású füszerek, vitaminok alkalmazása az élelmiszerekben. Ezeket az élelmiszereket a szakirodalom funkcionális élelmiszereknek nevezi (SZAKÁLY, 1994; BIRÓ, 2004; HAWKES, 2004). A funkcionális élelmiszerek piaci részesedése évről évre növekszik, s egyre inkább az élelmiszeripar húzótermékeivé válnak (MENRAD, 2003; PISKÓTI et al., 2006). A fejlődés oka, hogy az emberek többsége úgy véli, hogy az általa fogyasztott élelmiszerek közvetlenül hozzájárulnak az egészsége megőrzéséhez, javításához (MOLLET és ROWLAND, 2002; YOUNG, 2000; BARNA, 2007; MENDIS et al., 2011).

Manapság a folyamatos változásnak köszönhetően sokszor problémát jelent, hogy mit ajánlott és mit nem ajánlott enni, vagy hogy mit is jelent az egészséges táplálkozás. Fontos tisztázni azt a tényt, hogy az egészséges táplálkozás alatt nem a köztudatban egészségesnek titulált ételek fogyasztását értjük, hiszen manapság a forgalomba hozott ételek többsége egészségesnek tekinthető. HIDVÉGI et al. (2015) megfogalmazása szerint: „Az egészséges táplálkozás a különféle ételek és italok megfelelő arányban és mennyiségben, kellő változatossággal történő rendszeres fogyasztását jelenti. Ezáltal a beteg- ségek kockázatát minimálisra csökkenthetjük. Az egészséges étrendnek megfelelő mennyiségben kell tartalmaznia a szervezetünk számára fontos energiát adó tápanyagokat (fehérjéket, zsírokat, szénhidrátokat) és energiát nem adó tápanyagokat (vitaminokat, ásványi anyagokat és nyom-elemeket). Próbáljunk változatosan táplálkozni minél többféle nyersanyag felhasználásával, a lehető legtöbbféle készítési módot alkalmazva" (HIDVÉGI et al., 2015:39). Mindemellett a táplálkozás és az élelmiszer-biztonság szorosan összefügg, mely az elmúlt évtizedekben a különböző élelmiszerbotrányok hatására a fogyasztói bizalom megrendülését okozta. A „nem biztonságos ételek” fogyasztása egészségügyi kockázatot jelent, éppen ezért a WHO folyamatosan arra törekszik, hogy mindenki számára elérhetővé tegye a biztonságos élelmiszereket (BÁNÁTI, 2011; WHO, 2019).

A táplálkozási ajánlások szemléltetésének egyik általánosan elterjedt formája a táplálkozási piramis, mely táplálkozás-élettani szempontból az élelmiszereket 4 különböző táplálékcsoportba sorolja. Az egészséges étrend fó alapelve, hogy a szervezetünk megfelelő arányban kapja az alapvető tápanyagokat. A piramis lényege abban áll, hogy a helyes és kiegyensúlyozott étrendet kell kialakítani a különbözó tápanyagok megfelelő kombinációjával azért, hogy megőrizzük egészségünket. Fontos hangsúlyozni, hogy az elmúlt évtizedekben számos táplálkozási piramis látott napvilágot, s a legtöbbet emlegetett az USA Mezőgazdasági Minisztériuma (USDA) által alkotott táplálkozási piramis, melyet 1992-ben ábrázoltak először, majd 2005-ben átdolgoztak, s 2011-ben táplálkozási „okostányér” formájában aktualizáltak. A piramis alapja, hogy az étkezésünket leginkább meghatározó élelmiszercsoportok a piramis alján találhatók, s ahogy egyre haladunk a csúcs felé, annál inkább ajánlott a takarékos felhasználás, ahol például a zsírok, olajok, édességek találhatók (WELSH et al., 1992). A 2005-os koncepció már több mint egy iránymutatás, hiszen lényegében az elmúlt 30 évben nem változtak az alapelvek, csak más üzenetet hordoz. A tányérkoncepció is a gyakorlati megvalósítást segíti, hiszen megmutatja, hogy mi van a tányérunkon, s szemlélteti a kenyér és gabonafélék, zöldségek, gyümölcsök, fehérjék és tejtermékek egészséges arányát a mindennapi 
étkezési szokásainkban, valamint ajánlásokat is tartalmaz (HAVEN et al., 2006). Az alappiramis mellett napjainkban egyre inkább elterjedt az 1990-ben kifejlesztett speciális, mediterrán étkezési piramis is, melynek leggyakoribb elemei közé tartoznak a gyümölcsök, a zöldségek, a gabonafélék, az olívaolaj, a bab, a hüvelyesek, a diófélék, a magvak, a gyógynövények, a füszerek, valamint a halak és haltermékek. Miután a

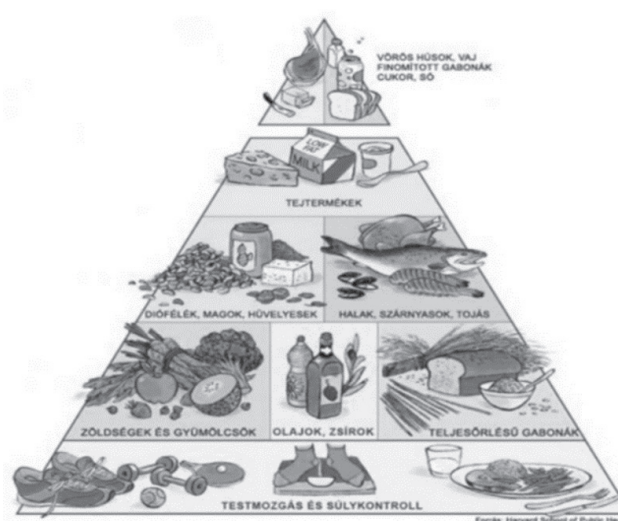

halak és a tenger gyümölcsei az egészségtudatos életmódban fontos szerepet töltenek be, kiemelt elemként jelennek meg itt is, melyet hetente többször fogyaszthatnak, a baromfihús, a tojás, a joghurt és tejtermékek mérsékeltebben, míg a vöröshúsok, és az édességek csekélyebb mértékben fogyasztandók (BACH-FAIG et al., 2011; DAVIS et al., 2015).

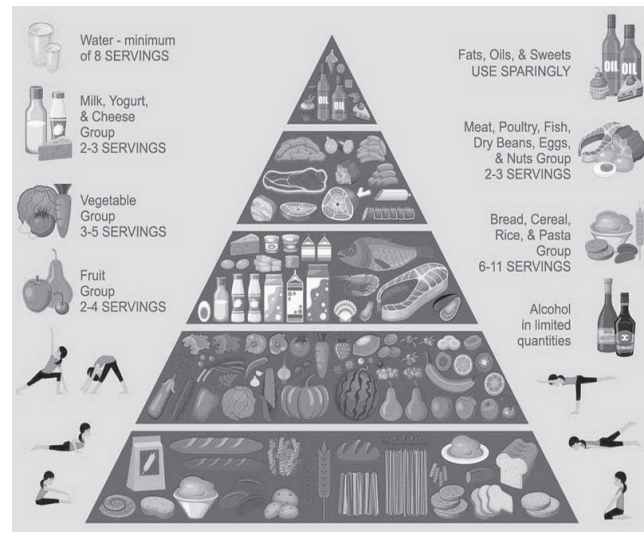

FIG. 1

1. ÁBRA

Táplálkozási piramisok

(Healthy Diet Pyramids)

Forrás (Source): Harvard School of Public Health, 2013; Rang, 2016

Kutatók szerint az egészséges táplálkozás kialakításához és annak fenntartásához a testmozgás és a napi rendszeres étkezések megléte egyaránt hozzájárul. A globális sportpiac növekedése évről-évre meghaladja a GDP növekedés ütemét, s hazánkban is a sportolás és a mindennapi testmozgás iránti igény növedékese figyelhető meg (BÁCSNÉ et al., 2018). Azt is fontos hangsúlyozni, hogy általában nem az ételek mennyisége, hanem a minősége kap kiemelt szerepet a mindennapi kiegyensúlyozott, egészséges táplálkozás során. Az étrend alapját a rostban gazdag gabonafélék alkotják, hiszen a gabona alapvető fontossággal bír az egészségünket illetően. A finomított liszt, fehér rizs, fehér kenyér helyett inkább teljes kiőrlésü tészta vagy barna rizs fogyasztása a célszerü. Az étkezések során sok zöldségnek és gyümölcsnek, valamint teljes kiőrlésű gabonáknak, magoknak és az egészséges zsiradékoknak hetente többször is szerepelnie kell, ezen túl törekedni kell a változatosságra. Emellett előnyben kell részesíteni az egészséges fehérjeforrásokat is, mint pl. a fehér húsokat vagy halat a vörös húsok helyett. A piramis csúcsán az édességek és a zsiradékok szerepelnek, melynek fogyasztását a többi táplálékhoz viszonyítva a legalacsonyabb szinten kell tartani (RODLER, 2005; BALÁZS, 2010; HUSZKA, 2012; SÓLYOM, 2014).

Az ember fejlődése során, sajnálatos módon, jelentős részben elveszítette a táplálék kiválasztásának természetes ösztönét. Étrendjét alapvetően a szűkebb és tágabb környezet szokásai, szabályai, a társadalmi értékrend, hiedelmek határozzák meg. Ezért táplálkozni is meg kell tanulni. A megváltozott és felborult táplálkozási szokások helyes mederbe való visszatereléséhez fontos lenne az egészségtudatos táplálkozás széles körü megismertetése a lakossággal, melyben nagy szerepe lehetne az egészséges, illetve egészségvédő (funkcionális) élelmiszereknek. Mindezen információk birtokában a fejlett országok fogyasztói egyre több gondot fordítanak egészségük megőrzésére, mind több információt szereznek az egészséges életmódról, s a gyógykezelés helyett a betegsé- 
gek, az egészségi állapot leromlásának megelőzésére törekednek (ENSER, 2001).

A táplálkozás vizsgálata során fontos megjegyezni azt a tényt, hogy a szakirodalom által helyesnek vélt ételek rendszeres vagy kevésbé rendszeres fogyasztását sok más tényező is befolyásolja, mint például a különböző ételérzékenység, ételallergia, vagy akár a vallás. Az európai kultúrában a kereszténység nem ír elő élelmiszerfogyasztásra vonatkozó tiltásokat, azonban vannak olyan kultúrák, ahol jelentős korlátozások vannak egyes ételek tekintetében, fóként a húsfogyasztásra vonatkozóan (VIDA és SZƯCS, 2016).

Táplálkozásunkat és egészséges életmódunkat nagyban befolyásolja a szülői minta, vagyis a szülők példamutatása, hozzáállása az egészséges életmódhoz, mely fóként fiatalkorban alakul ki. Emellett a fiatal korosztály sokat tehet ezen kívül is egészségéért és annak megőrzéséért (BERKE et al., 2012). Éppen ezért vizsgálatunk középpontjába a fiatal egyetemisták táplálkozási szokásait helyeztük, hiszen ezen korosztály egészségtudatosságának vizsgálata kitüntetett szerepet kap mind hazai, mind nemzetközi szinten egyaránt. A téma aktualitását a felgyorsult világunknak köszönhető rohanó életmódból eredő hektikus táplálkozási metódus jelenti. Nemzetközi szinten komoly problémát jelentenek a fiatalok körében megjelenő betegségek, melyek egyaránt összefüggenek a táplálkozásukkal és az életmódjukkal. Egyre több kutatás igazolja, hogy a fiatalok étkezési szokásai komolyabb egészségügyi problémákat eredményeznek, mint például a túlsúly, a cukorbetegség, a szívbetegség, a keringési problémák, az emésztőrendszeri betegségek, vagy esetleges rákos megbetegedés, melyeket tovább fokoz a mozgáshiány, a dohányzás, valamint az alkoholfogyasztás is (SZAKÁLY, 2011; MCGINNIS et al., 2006). Magyarországon a teljes népesség körében egyre magasabb az elhízottak aránya, mely megfigyelhető már a fiatalok körében is. A túltápláltság kialakulása az öröklött hajlam mellett döntőképp a helytelen táplálkozásban és a mozgásszegény életmódban keresendő. Hazánkban elmondható, hogy - a WHO által használt, a testmagasság és a testtömeg alapján meghatározott testtömeg index (BMI= Body Mass Index) alapján, mely szerint $30 \mathrm{~kg} / \mathrm{m}^{2}$ érték felett tekintünk valakit elhízottnak minden második ember tekinthető túltápláltnak (NÉPEGÉSZSÉGÜGYI JELENTÉS, 2015). Éppen ezért az egészséges és kiegyensúlyozott (megfelelő minőségű és mennyiségü tápanyagbevitelt tartalmazó) táplálkozás ösztönzése és figyelemfelkeltése az egyik legfóbb feladat (MARJAINÉ et al, 2012). A különböző kutatások megfigyelései alapján indokolttá válik az egyetemisták (20 és 30 év közöttiek) táplálkozási szokásainak felmérése, megismerése, hiszen ez a korosztály már önálló választást hoz saját étkezéseit illetően. Fontos megvizsgálni, hogy ezen korosztály tagjai saját döntéseik birtokában mennyire tekinthetők egészségtudatosnak, hiszen még vélhetően nem esetek át komoly betegségeken (kivételt képeznek a valamilyen ételérzékenységben szenvedők). E korosztály esetében megfigyelhető, hogy sokkal inkább az örömforrás céljából esznek, az ízvilág, a divathóbort, a reklámok erősen befolyásolják az élelmiszer-preferenciáikat. Az étel nemcsak tápanyagforrást jelent számukra, hanem egyre inkább státuszszimbólummá is válik (PAPP és LUGOSI, 2018).

Napjainkban változás figyelhető meg az étkezés tekintetében, hiszen a rohanó életmódnak köszönhetően megváltozik a mindennapi ritmusunk, átalakul a hagyományos 3 alkalmat magában foglaló napi étkezés jelentősége, valamint fontosabbá válnak a gyorsan elfogyasztható ételek. Új rendszerek alakulnak ki, hiszen az étkezések tartalma mellett annak fogyasztási helye is megváltozik, melynek egy részét különféle divatőrületek, reklámok vagy bloggerek trendjei határozzák meg. Éppen ezeknek köszönhetően a food-trendek sorában egyre nagyobb szerepet kap a nagyobb csoportok elkülönítése, olyan tényezők mentén, mint a gyorsaság és a kényelem, a környezet és a felelősség, az egészség és az élmény által vezérelt ételek fogyasztása (TÖRŐCSIK, 2007). A food-trendek rendszere a csoportosítás alapján néhány népszerübb trend:

1. gyorsaság, kényelem:

a. fast food (valamit gyorsan),

b. street food (utcán gyorsan beszerezhető ételek),

c. call food (gyorsan házhoz),

d. finger food (kézzel fogyasztható gyorsétel), 
e. convenience food (otthon elkészíthető kényelmi ételek pl. fagyasztott, félkész termékek) (BERRY, 1979; TÖRÓCSIK, 2007).

2. környezet, felelősség (egészség- és környezettudatosság):

a. bio-food (vegyszermentes, természetességet biztosító ételek),

b. authentic food (a termelő hitelessége),

c. trusted food (azt fogyasztja a vásárló, amit ígértek neki),

d. SOS food (Save Your Society) és harmony food (fenntartható fejlődés érvényesítésével készült ételek),

e. local food (lakóhely közelében termelők alapanyagainak felhasználásával készült ételek) vagy a slow food (adott területre tradicionális ételek készítése és fogyasztása) (PETRINI, 2002).

3. egészség, tudomány:

a. healthy food (természetes eredetű, egészségünkre jótékony hatású élelmiszerek),

b. superfood (természetes funkcionális hatású élelmiszer),

c. functional food (funkcionális élelmiszer),

d. clean food (allergiát okozó tényezők kiszürésével készített élelmiszer)

4. élmény, szakértelem:

a. mood food (pozitív érzelmi többletet adó élelmiszer) (BOSCH et al., 2005),

b. wellness food (életérzés közvetítése az étkezés mellett),

c. show food (egyfajta élménytöbbletet biztosító ételek pl. mesterszakácsok ételei, ételkülönlegességek),

d. fúziós konyha (különleges ételek beépítése a hétköznapi étkezésekbe),

e. retro food (nosztalgikus ételek),

f. strange food (általunk nem fogyasztott különlegességek fogyasztásának trendje) (TÖRÖCSIK, 2007).

A kutatásunk elsődleges célja tehát feltérképezni azt, hogy debreceni egyetemisták mindennapos étkezési szokásai mennyire követik a dietetikusok által megalkotott egészségtudatos és helyes táplálkozáshoz szükséges élelmiszerek táplálkozási piramisának ajánlásait, különös tekintettel az étkezések gyakoriságára és minőségére. Kutatásunk során a célkitüzéssel összefüggésben megfogalmazott kérdéseink, melyek megválaszolására törekszünk:

- Mi jellemzi a hallgatók étkezési gyakoriságát?

- Milyen alapanyagok fogyasztása jelenik meg a debreceni egyetemisták táplálkozása során?

- Mennyire követi a hallgatók táplálkozása a szakemberek által megalkotott táplálkozási piramis ajánlásait?

A kérdések megválaszolásához rendelt feladatok a következők voltak:

- A hallgatók mindennapos fogyasztási szokásainak felmérése és értékelése.

- A hallgatói táplálkozási gyakorlat táplálkozási piramissal való összevetése.

\section{ANYAg ÉS MóDSZer - MATERIAL AND METHOD}

Kutatómunkánkat az általános módszertani ajánlásokat követve szekunder adat- és információgyüjtéssel kezdtük, melynek során a témához kapcsolódó szakirodalmak összegyưjtését és feldolgozását, rendszerezését végeztük el. A kutatási téma vizsgálatához a legjobban illeszkedő, legfrissebb, releváns forrásokat kutattuk fel, hazai és nemzetközi modelleket és kutatási eredményeket elemeztünk. A célkitüzés érdekében a szekunder kutatás kiegészítéseként primer vizsgálat elvégzése is szükséges volt.

Először a kutatások során az egyik leggyakrabban alkalmazott kvalitatív (minőségi) kutatási módszert alkalmaztuk, a Debreceni Egyetem hallgatóinak egy csoportjával egy fókuszcsoportos interjút készítettünk, mely során olyan véleményeket, észrevételeket, problémákat tártunk fel, mely a kutatásunk előmenetelét segítette. Az interjúalanyok véleménye számos esetben segítette egy-egy kérdés válaszlehetőségeinek módosítását, esetleges bővítését. A fókuszcsoport vizsgálat során a Debreceni Egyetem minden karáról kiválasztásra került 1-1 ember, véletlenszerűen a neptun kód alapján. A fókuszcsoportos interjúra 2019 elején került sor 14 fő bevonásával. A vizsgálat során főként az alapvető fogyasztói szükségletek kérdéskörét elemeztük, különös tekintettel a hallgatói 
célcsoportra. A fókuszcsoportos interjú során közel azonos, egymással összevethető kérdéseket tettünk fel a kiválasztott hallgatóknak. A kérdéseket 4 fó kérdéscsoportba soroltuk, melyek által minden résztvevő elmondhatta a véleményét és tapasztalatait a hallgatói korosztály étkezéseiról, az étkezések gyakoriságáról, a bevitt folyadékok mennyiségéről és minőségéről, valamint a fogyasztott élelmiszerek elkészítésének módjáról, beszerzési helyéről. A vizsgálat során elhangzott megállapításokat, konklúziókat a beszélgetés során rögzítettük, majd a kiértékelésüket papíralapon végeztük el.

A további kutatást egy leíró kutatási módszerrel, a megfigyeléses eljárással folytattuk le, mely során véletlenszerú kiválasztással ételfogyasztási napló/étkezési napló készítését tartottuk indokoltnak annak érdekében, hogy megfigyelhessük, hogy milyen minőségü és mennyiségü ételeket fogyasztanak a hallgatók étkezéseik során. A hallgatók kiválasztása során a véletlenszerü mintavétel alapját a Debreceni Egyetem hallgatóinak egyedi azonosítója (neptun kódja) jelentette, hiszel a 6 karakterből álló kód (szám és betű különböző kombinációja) esetében előre meghatároztunk 3 karaktert, s olyan hallgatók kerültek bele a vizsgálatunkba, akiknek az általunk kiválasztott karakterek szerepeltek az egyedi azonosítójukban. Így az egyetem hallgatói közül 25 fő került kiválasztásra, akik étkezési szokásait étkezési naplóval mértük. A kiválasztott hallgatók nem szerinti megoszlásáról elmondható, hogy 9 férfi/fiú és 16 nő/lány került kiválasztásra. A napló vezetése során a hallgatók 1 héten keresztül minden nap az általuk fogyasztott élelmiszereket vezették, valamint külön feltüntették az ételek elfogyasztásának idejét, az étel mennyiségét részegységekre bontva, annak beszerzési helyével együtt. Az ételek feltüntetése esetében meg kellett határozni az élelmiszer pontos márkanevét, terméknevét, valamint a főtt ételek esetében az étel nevét úgy, hogy következtetni lehessen az ételt alkotó nyersanyagok fajtájára és a készítési módjára. Az elfogyasztott italok esetében fel kellett tüntetni gyümölcslé esetén annak gyümölcstartalmát: szürt, 12\%, 25\%, 50\%, 100\%; üdítőitalok esetén, hogy light, zéró vagy normál; szörpök esetén, hogy bolti vagy otthon készített; továbbá az ásvány- vizek esetében, hogy savas, mentes vagy ízesített, valamint a márkát is. A napló vezetése során külön fel kellett tüntetni az édesítéshez használt cukrot, mézet és ezek mennyiségét, az ételkészítéskor felhasznált zsiradéktípust, a kenőzsiradék típusát, márkáját, zsírtartalmát és a felhasználás mennyiségét, a kenyér, péksütemény típusát és vastagságát, a nassolásokat, étkezések között elrágcsált falatokat. Az ételek, élelmiszerek közvetlen fogyasztása során történő sózás mennyiségét, a felhasznált ételízesító anyagokat és a felhasznált kényelmi termékeket (pl. levespor). Az egyes étkezések esetén külön meg kellett határozni, hogy otthon, étteremben, gyorsétteremben, büfében, munkahelyi étteremben, iskolai étteremben, házhoz szállító cégnél vagy egyéb helyen készítették az elfogyasztott ételeket.

Az összegyưjtött adatok és információk rendszerezését a Microsoft Excel programban végeztük el, ahol a fogyasztott élelmiszerek mennyiségét és fogyasztásának gyakoriságát először minden hallgatóra külön-külön, majd összevontan is meghatároztuk. A naplóban egyaránt ki kellett mutatni az ételek mellett a fogyasztott italok körét is. A begyüjtött adatok által meghatározhatóvá vált számunkra, hogy a kiválasztott hallgatók milyen rendszeresen és milyen időközönként étkeznek. Emellett pedig a begyújtött és rendszerezett lista a fogyasztott élelmiszerekről lehetővé tette számunkra, hogy a táplálkozási piramisban elkülönített 4 csoport szerint osztályozva elkülöníthessük az ételeket, s ezáltal a mindennapos fogyasztási szokásokat értékelni tudjuk. Fontos megjegyezni, hogy a bemutatott eredmények egy nagyobb, folyamatban lévő kutatás egy részét képezik.

\section{EREDMÉNYEK - RESUlts}

A fókuszcsoportos interjú alapján kiderült, hogy a hallgatók két csoportját célszerü elkülönítenünk, hiszen teljesen más a megítélése táplálkozás szempontjából az otthon élő és a családjától külön élő (albérletben vagy kollégiumban élő) diákoknak. A családjával élő hallgató esetében a szülők gondoskodnak többségében az ételek elkészítéséről, a külön élők pedig a saját maguk által készített ételt fogyasztják. Többen úgy vélekedtek, hogy a 
többszöri étkezés ugyan megvalósul a hallgatók mindennapjaiban, azonban azok minősége már nem megfelelő, s nem tekinthető rendszeresnek. Ezt alátámasztja, hogy az interjúalanyok egyöntetűen megállapították, hogy a diákok hetente legalább 2-3 alkalommal fogyasztanak gyorséttermi ennivalót, emellett pedig kevés alkalommal fogyasztanak meleg ételt, azon belül is legkevésbé leveseket.

A hallgatói lét másik nagyobb kérdésköre a rendszeres és minőségi étkezés mellett az elfogyasztott innivalók minősége. A résztvevők egyöntetúen úgy vélekedtek, hogy a hallgatók mindennapi folyadékbevitele nem megfelelő, hiszen főként cukros üdítőitalokat fogyasztanak. Ezen felül rendszeres az alkohol fogyasztása is, valamint a kávé vagy energiaitalok kiemelten megjelennek a mindennapjaikban. Fontos hangsúlyozni, hogy a hallgatói lét egy szemeszter esetében két részre osztható, hiszen a szorgalmi- és a vizsgaidőszak kettőssége jellemzi. A kutatásunk főként a szorgalmi időszakra vonatkozott, hiszen úgy gondoljuk, hogy a rendszeres és általánosnak tekinthető étkezési magatartás ebben az időszakban vizsgálható a leghitelesebben.

A fókuszcsoportos interjú kiegészítéseként az étkezési naplóból származó adatok és információk segítséget nyújtanak számunkra, hogy a kutatásunkban megfogalmazott kutatási kérdéseket meg tudjuk válaszolni. Az étkezési naplóból begyújtött adatok alapján megalkotott táplálkozási piramist a 2. ábra illusztrálja.

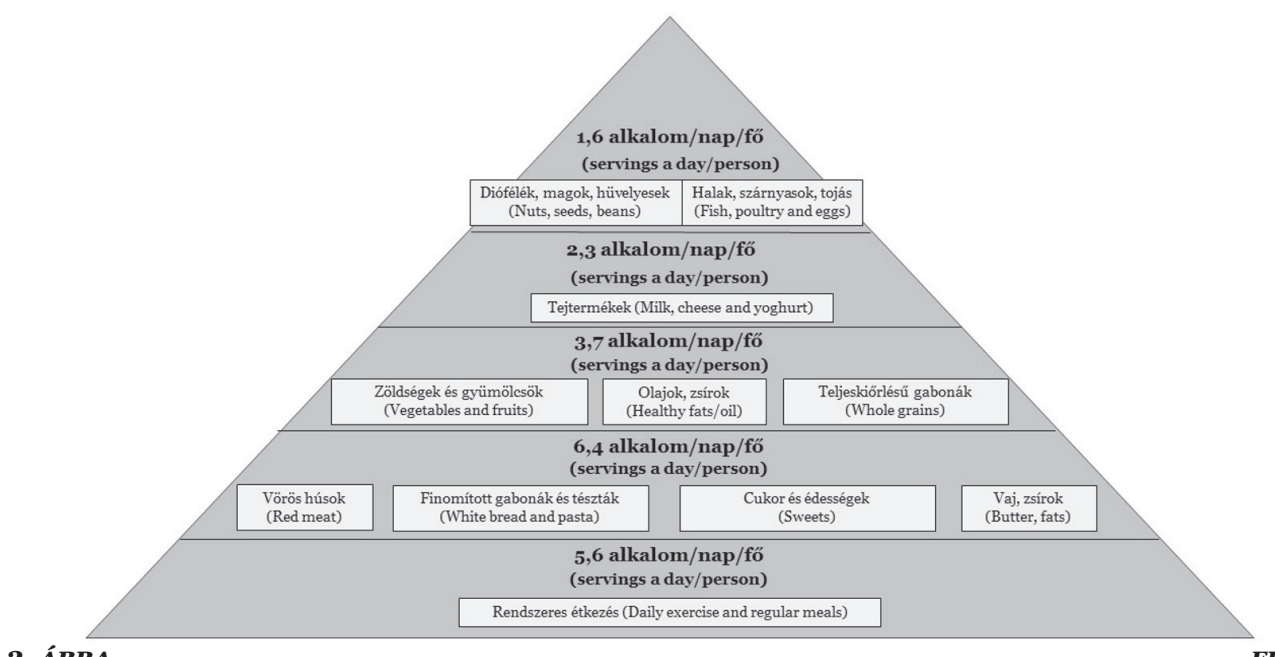

2. ÁBRA

Debreceni egyetemisták táplálkozási piramisa

FIG. 2

(Healthy Diet Pyramid of Students at the University of Debrecen)

Forrás (Source): Saját szerkesztés (Own compilation)

A helyes táplálkozás elvei alapján, ahogy haladunk a táplálkozási piramis csúcsa felé, az egyes szinteken feltüntetett élelmiszereket minél ritkábban kell heti rendszerességgel fogyasztani. Azonban a kapott adatok azt mutatják, hogy a debreceni egyetemisták körében pont ellentétes tendencia figyelhető meg, hiszen a napi étkezésben legtöbbször vörös húsok, tésztafélék, finomított gabonák, cukrok, só, valamint az alkohol van jelen. Kijelenthető, hogy a hallgatók táplálkozási piramisa jelentősen eltér a szakirodalom, illetve a dietetiku- sok ajánlásaitól. Ezen belül is az édességek és cukrok tekintetében figyelhettünk meg kiugró értékeket, hiszen egy hét alatt 14,7 alkalommal voltak jelen egy egyetemista étkezésében valamilyen formában, s ennek döntő többsége fehércukor volt, nem méz vagy édesítőszer. A megkérdezett hallgatók közül 4 esetében tapasztaltuk, hogy mézet használ, míg 7 hallgató az édesítőszert preferálja édesítés céljából. Emellett a kávé fogyasztása változó képet mutat, hiszen átlagosan mintegy 7,4 alkalom/fö/ hét értéket kaptunk, mely hozzávetőlegesen 
napi 1 kávét jelent, azonban ha figyelembe vesszük, hogy a megkérdezettek egy része nem, vagy alig fogyaszt kávét, úgy kijelenthető, hogy a kávét fogyasztók napi 1-nél több alkalommal isszák azt. A hallgatók fele úgy nyilatkozott, hogy 8 kávénál többet fogyaszt egy hét alatt, azonban volt olyan hallgató, aki a vizsgált egy hét alatt mintegy 18 kávét fogyasztott, így ezt kiugró értéknek tekinthetjük.

A szakirodalom alapján a helyes táplálkozás érdekében gyümölcsökből, zöldségekből, egészséges olajokból, valamint a teljes kiőrlésủ gabonákból kellene a legtöbbet fogyasztani (például naponta legalább háromszor kellene fogyasztani zöldség- és főzelékféléket, valamint gyümölcsöket). Ezzel szemben az eredményeink azt mutatták, hogy ez a kategória 42\%-kal kevesebbszer jelenik meg a fogyasztásban, mint a legkevésbé ajánlott élelmiszerek. A vizsgált kategóriában a zöldégek fogyasztása volt a kiemelkedő, mintegy 10,1 alkalom/fo"/hét érték alapján, melyek közül is a paradicsom, a paprika és az uborka fogyasztása jellemző. Azonban szembetűnő tény az is, hogy a fiatalok kevés gyümölcsöt fogyasztanak, egy före vetítve hetente mindössze 5,6 alkalommal. A fogyasztott gyümölcsök közül meghatározó a banán, alma és a narancs.

A következő kategória a tej- és tejtermékek, mely a kutatásunk alapján fóként a kávé mellett jelenik meg, s ezenkívül jelentős még a különböző sajtkészítmények fogyasztása is, mely együttesen heti 16,1 alkalom/fó értéket képvisel. A mennyiség tekintetében alkalmanként 1-2 dl között változik a tejfogyasztás, mely lemarad a WHO ajánlásától, mely szerint minden nap kellene szerepelnie az étrendünkben. Naponta 0,5 liter tejet, illetve rendszeresen alacsony zsírtartalmú sajtokat, túrót, joghurtot kellene fogyasztani.

Megfigyelhető, hogy a fogyasztott húsok fóként a szárnyasokra koncentrálódnak, hiszen az összes hús tekintetében a szárnyasoknál jött létre a legmagasabb eredmény, mintegy 7,0 alkalom/fő/hét fogyasztással. Emellett azonban magas a sertéshús fogyasztása is. A húsok fontos szerepet töltenek be az egészséges táplálkozásban, emiatt ajánlott naponta 2-3 alkalommal húst, húskészítményt fogyasztani. A halak fogyasztása a diákok körében nagyon alacsonynak mondható, hiszen a heti 1 alkalmat sem éri el egy före vetítve (o,6 alkalom/fó/hét), amely a dietetikusok ajánlásának megfelelő érték.

Az ajánlással megegyezően az olajos magvak fogyasztására a heti 2-3 alkalom értéket realizáltuk, mely esetében 1-1 kis maréknyi nem sózott olajos magvat, például mandulát, diót, tökmagot jelentett, mely kiegészíti a tízórait vagy uzsonnát.

A megkérdezettek étkezéseinek gyakoriságáról elmondható, hogy a kimutatott átlagos napi 5,6 étkezés megfelelő, azonban rendszertelen étkezéseket mutatott a napló, mely a szervezet számára megterhelő.

Az ételek fogyasztása mellett a folyadékbevitel is meglehetősen alacsony értékeket mutat, hiszen 1,8 liter/fö/nap fogyasztást mutattak a naplók az ajánlott 2,5 liter/fö/nap helyett, mely képet tovább rontja, hogy ez az érték magában foglalja az üdítők és a víz fogyasztását is. Az elfogyasztott folyadék tekintetében elmondható, hogy 73,4\%-a víz, 16,7\%-a cukros üdítő, 9,5\%-a tea és csupán 0,4\%-a az energiaital az összfogyasztásnak. Az irányelv szerint szomjúság oltására inkább víz, ásványvíz fogyasztása ajánlott a cukrozott italok helyett. A folyadékbevitelhez csupán 3,1 alkalommal társul még heti szinten 1 fóre vetítve a levesfogyasztás, mely összességében nem elegendő egy egészséges szervezet fenntartásához.

A folyadékbevitel mellett az alkoholfogyasztás 1,9 alkalom/fö/hét, mely alapján megállapítható, hogy a vizsgált hallgatók átlagosan 2-szer fogyasztanak alkoholt egy héten, s a megkérdezett hallgatók 56\%-a esetében volt alkoholfogyasztás tapasztalható. Az alkoholfogyasztás tekintetében megfigyelhető volt, hogy a fogyasztott alkoholféleségek közül a röviditalok fogyasztásának a gyakorisága volt kimagasló, mintegy 17 alkalom/hét/megkérdezettek száma mértékben. Mindemellett a bor fogyasztásának gyakorisága megelőzte a sör fogyasztását, azonban csak csekély mértékben. Elmondható tény az is, hogy a borfogyasztás jellemzően a nők alkoholfogyasztási szokását jellemzi, hiszen a bort fogyasztó hallgatók 75\%a ehhez a nemhez tartozik.

A kutatás alapján beigazolódott, hogy a hallgatók többször esznek „szárazat”, meleg étel helyett, azonban a fókuszcsoportos interjúban elhangzottakkal ellentétben heti szinten nem tudtunk kimutatni magas gyorséttermi fo- 
gyasztást. A vizsgált hallgatók közül mindöszsze 4 számolt be gyorséttermi fogyasztásról, de ezek is csak egy-egy alkalmat jelentettek a vizsgált időszakban. A gyorsétterem mellett viszont egyre népszerúbb a házhozszállítási lehetőség, mely főként pizzára, gyrosra és hamburgerre összpontosul.

\section{KöVETKEZTETÉSEK ÉS JAVASLATOK - CONCLUSIONS AND PROPOSALS}

A fókuszcsoportos interjú és az étkezési napló eredményét összevetve megállapítható, hogy a hallgatók rendszertelen, de átlagosan megfelelő mennyiségú napi étkezése főként a rosszabb minőségü élelmiszerekre csoportosul. Mindazonáltal a fókuszcsoportos interjún elhangzottakhoz képest az étkezési naplókból begyújtött adatok azt mutatták, hogy a hallgatók fogyasztásában nem jelennek meg hetente több alkalommal a gyorséttermi láncok termékei, sokkal inkább az otthon előállított ételekre koncentrálódik. Ezen eredményekre alapozva javasoljuk a rendszeres étkezés fontosságának fokozottabb hangsúlyozását az egyetemi hallgatói korosztály egészségesebb életvitele érdekében. Ennek egyik módja a büfékben, egyetemi éttermekben a „fitness” vagy egészséges ételek kínálatát növelni, így a hallgatók is könnyebben juthatnának hozzá ezekhez a termékekhez.

$\mathrm{Az}$ étkezések rendszertelensége mellett a folyadékbevitelt illetően figyelhető meg probléma, hiszen az átlagos napi 1,8 liter/fő folyadékbevitel elmarad az ajánlottól, bár ez egyénenként nagy eltéréseket mutatott, napi o,7 liter és 3,4 liter közötti intervallumban ingadozott a megkérdezettek esetében. Elmondható az is, hogy a vizsgálatban részt vevook $56 \%$-a napi 2 liternél kevesebb folyadékot fogyaszt, s csupán csak 19\%-a, akik az ajánlott 2,5 liternél több folyadékot fogyasztanak. Az összfogyasztás esetében a víz mellett $(73,4 \%)$ legnagyobb mértékben, 26,6\%-ban a cukros üdítők jelennek meg, ezen felül elenyésző részben az energiaitalok. A folyadékbevitel elősegítésének egy módszere, hogy a leves formájában történő folyadékpót- lást is hangsúlyozni kellene, hiszen az optimális mennyiségű folyadékbevitel a szervezet megfelelő múködéséhez elengedhetetlen.

$\mathrm{Az}$ étkezések részelemeit vizsgálva magas érték mutatkozott az édességek tekintetében, mely többek között magas cukorfogyasztásra is utalhat. Ezen érték gyakoriság szempontjából legfőképp a koffeintartalmú italok fogyasztása (kávé, tea) mellett számít rendszeresnek, azonban a megkérdezettek gyakran fogyasztanak édességeket is (sütemény, édes keksz). A megkérdezettekre vetítve átlagosan 2,1 alkalommal fogyasztanak napi szinten valamilyen magas cukortartalmú terméket. Ezen italok esetében a megkérdezettek többsége nem természetes édesítőszereket alkalmaz, mint például a méz. Az egészséges életmód kialakítása érdekében a természetes édesítőszerek térnyerése különösen fontos kritérium lenne.

\section{5. ÖSSZEFOGLALÁS - SUMMARY}

Összességében megállapítható, hogy a begyưjtött és elemzett adatok alapján a vizsgált korosztály étkezési szokásai elmaradnak a szakirodalom által egészségesnek vélt táplálkozási struktúrától. A hallgatók fogyasztása szerint összeállított táplálkozási piramis elemei a fogyasztási gyakoriság alapján felcserélődnek, hiszen a legtöbbet fogyasztott élelmiszerek a vöröshúsok, finomított gabonák, tészták és édességek kategóriái, melyek az ajánlás alapján a legkisebb mértékben fogyasztandók. A fogyasztási struktúra alján gyakoriság tekintetében következnek a zöldségek, gyümölcsök és teljeskiőrlésű gabonák, majd ezt követik a tejtermékek, s a legkevésbé fogyasztott kategória a diófélék, magok, hüvelyesek, valamint a halak, szárnyasok és a tojás. A teljes piramist nézve megállapítható, hogy az elfogyasztott ételeket illetően a kiugró értéket mutató alsó szegmens mellett a többi érték is elmarad az ajánlott gyakoriságtól. A fogyasztás esetében a hal és haltermékek, a baromfihús-, hústermékek, valamint a tojás esetén tapasztalható alacsony érték meglepő, hiszen mindegyik termék egészségügyileg jótékony hatású, s fogyasztása kiemelten fontos. 


\section{KöSZÖNETNYILVÁNÍTÁS -}

\section{ACKNOWLEDGEMENT}

A publikáció elkészítését az EFOP-3.6.1-162016-00022 számú projekt támogatta. A projekt az Európai Unió támogatásával, az Európai Szociális Alap társfinanszírozásával valósult meg.

\section{IRODALOMJEGYZÉK - REFERENCES}

Bach-Faig, A. - Berry, E. M. - Lairon, D. - Reguant, J. - Trichopoulou, A. Dernini, S. - Medina, F.X. - Battino, M. - Belahsen, R. - Miranda, G. Serra-Majem, Ll.: Mediterranean Diet Pyramid Today. Science and Cultural Updates. Mediterranean Diet Foundation Expert Group. Public Health Nutrition. 2011. 14 (12A) 2274-2284.

Bácsné Bába, É. - Balogh, R. - Bács, Z. - Fenyvesi, V. - Dajnoki, K.: Sportszolgáltatások keresleti, kínálati oldalának elemzési lehetőségei. Studia Mundi - Economica 2018. 5 (3) 19-33.

Balázs, A.: Gyógynövények szerepe az elhízás megelőzésében és kezelésében. Orvosi Hetilap. 2010. 151 (19) 763-773. DOI: https://doi.org/10.1556/OH.2O10.28812

Bánáti, D.: Consumer Response to Food Scandals and Scares. Trends in Food Science \& Technology. 2011. 22 (2-3) 56-60. DOI: https://doi.org/10.1016/j. tifs.2010.12.007

Barna, M.: A táplálkozás és az egészség szempontjai az élelmiszeripar fejlődésében. Az élelmiszeripar jövője. ÉFOSZ, Élelmiszertechnológiai Platform, Földmúvelési és Vidékfejlesztési Minisztérium, Budapest 2007.06.20.

Berke, Sz. - Huszka, P. - Laki-Lukács, A. - Iglói, N.: Az egészséges életmód és a testmozgás megítélése kaposvári fiatalok körében. Vállalkozói és gazdasági trendek a Kárpát-medencében I. kötet (Szerk.: Fejér-Király, G., Lázár, E.). Státus Kiadó, Csíkszereda, 2012. 86-97.
Berry, Leonard L.: The Time-Buying Consumer. Journal of Retailing. 197955 (4) 58-69.

Biró, Gy.: Új funkcionális élelmiszer alkotórészek - A rosszindulatú daganatok és az oxidatív degradáció. Édesipar. 2004. 50 (4) 137-146.

Bosch, C. - Schiel, S. - Winder, T.: Emotionen im Marketing. Transfer. 2005. (1-2) 20-25.

Davis, C. - Bryan, J. - Hodgson, J. - Murphy, K.: Definition of the Mediterranean Diet; A Literature Review. Nutrients. 2015. 7 (11) 9139-9153. DOI: https://doi.org/10.339o/nu7115459

Enser, M.: „Hústermékek az egészséges táplálkozás szolgálatában” Beszámoló a hústudomány és Technológia 46. Nemzetközi Kongresszusáról. Buenos Aires, Argentína, 2000. augusztus 27. szeptember 1. In: A Hús. 2001. 11 (1) 9-30.

Harvard School of Public Health: Healthy Eating Plate. 2013. URL: https:// www.shape.hu/27778_egeszseges_ taplalkozasi_piramis_a_harvard_ kutatoitol és https://www.hsph.harvard. edu/nutritionsource/healthy-eatingplate/ (Letöltés dátuma: 2019.07.06)

Haven, J. - Burns, A. - Britten, P. Davis, C.: Developing the Consumer Interface for the MyPyramid Food Guidance System. Journal of Nutrition Education and Behavior. 2006. 38 124135. DOI: https://doi.org/10.1016/j. jneb.2006.08.002

Hawkes, C.: Nutrition Labels and Health Claims: The Global Regulatory Environment. World Health Organization. 2004. 1-88.

Hidvégi, P. - Kopkáné Plachy, J. Müller, A.: Az egészséges életmód (szerk: Hidvégi P.). Eszterházy Károly Főiskola, Sporttudományi Intézet, Eger, 2015.

Huszka, P.: Néhány gondolat a 13-14 éves korosztály táplálkozási szokásairól. „A marketing új tendenciái”. A Kautz Gyula Gazdaságtudományi Kar és a Regionálisés Gazdaságtudományi Doktori Iskola konferenciája. Győr, 2012. 12 (11) 236253. 
KSH: Egészségi állapot (2004-2018). 2019. URL: https://www.ksh.hu/thm/2/ indi2_8_1.html (Letöltés dátuma: 2019.10.10.)

Lim, S. S. et al.: A Comparative Risk Assessment of Burden of Disease and Injury Attributable to 67 Risk Factors and Risk Factor Clusters in 21 Regions, 1990-2010: A Systematic Analysis for The Global Burden of Disease Study 2010. Lancet. 2012. 380 (9859) 2224-2260. DOI: $\quad$ https://doi.org/10.1016/So14O6736(12)61766-8

Marjainé Szerényi, Zs. - Zsóka, Á. Kocsis, T. - Széchy, A.: A fiatalok fogyasztási és életmódbeli szokásai a környezeti nevelés tükrében. Új Pedagógiai Szemle. 2012. 62 (11-12) 15-36.

McGinnis, J. M. - Appleton Gootman, J. - Kraak, V. I.: Food marketing to chidren and youth. Threat or Opportunity. The National Academies Press, Washington, 2006.

Mendis, S. - Puska, P. - Norrving, B.: Global Atlas on Cardiovascular Disease Prevention and Control. World Health Organization. Geneva, 2011. URL: http://whqlibdoc.who.int/ publications/2011/9789241564373_eng. pdf (Letöltés ideje: 2019.05.20)

Menrad, K.: Market and Marketing of Functional Food in Europe. Journal of Food Engineering. 2003. 56 181-188. DOI: $\quad$ https://doi.org/10.1016/So26o8774(02)0o247-9

Mollet, B. - Rowland, I.: Functional foods: At the frontier between food and pharma. Current Opinion in Biotechnology. 2002. 13 (1) $483-485$.

Moreno, L. A. - Gottrand, F. Huybrechts, I. - Ruiz, J. R. González-Gross, M. - DeHenauw, S.: Nutrition and Lifestyle in European Adolescents: The Helena (Healthy Lifestyle in Europe By Nutrition in Adolescence) Study. Advances in Nutrition. 2014. 5 (5) 615-623. DOI: https://doi.org/10.3945/ an.113.005678
Népegészségügyi Jelentés: ÉszakMagyarországi Regionális Népegészségügyi jelentés 2015. URL: www.kormanyhivatal. hu/.../Regionalis...Jelentes_2015.pdf (Letöltés dátuma: 2019.07.02)

Papp, A. - Lugasi, A.: Finom, egészséges és népszerü - gasztronómiai kihívások gyermek és fiatalkorban. In: A magyar gyermekek és fiatalok életmódja: táplálkozás, testmozgás és lélek (Szerk.: Antal, E. - Pilling, R.). TÉT Platform Egyesület, 2018.

Petrini, C. (szerk.): A lassúság dicsérete. Egy könyv a zamatokról, a hagyományokról és az ételek élvezetéről. HVG könyvek, Budapest, 2002.

Piskóti, I. - Nagy, Sz. - Kovács, A. T.: Fogyasztói magatartás a funkcionális élelmiszerek piacán. In: Marketing Kaleidoszkóp, Miskolc, 2006. 117-127.

Popkin, B. M.: Global Nutrition Dynamics: The World Is Shifting Rapidly Toward a Diet Linked with Noncommunicable Diseases. American Society for Clinical Nutrition. 2006. 84 (2) 289-298. DOI: https://doi.org/10.1093/ajcn/84.2.289

Rang, V.: Food Pyramid. 2016. URL: https:// viralrang.com/food-pyramid/ (Letöltés dátuma: 2019.07.03)

Rodler, I. (szerk.): Új tápanyagtáblázat. Medicina Könyvkiadó Rt., Budapest, 2005.

Sólyom, A.: Múlt, jelen, jövő, avagy a tacit tudás-transzfer vállalati dimenziói. Idresearch Kft. - Publikon Kiadó, Pécs, 2014.

Szakály, Z.: Korszerü állati eredetű alapélelmiszerek piacképességének vizsgálata. Kandidátusi Értekezés, PATE, Állattenyésztési Kar, Kaposvár. 1994. 1-200.

Szakály, Z.: Táplálkozásmarketing. Mezőgazda Kiadó, Budapest, 2011.

Törőcsik, M.: Food-trendek és trendi vásárlói csoportok. Akadémiai Kiadó, Budapest, 2007.

Vida, V. - Szúcs, I.: Társadalmikulturális kérdések és a tradíciók szerepe a sertéshúsfogyasztásban. Táplálkozásmarketing. 2016. 3 (2) 7989. DOI: https://doi.org/10.20494/ $T M / 3 / 2 / 6$ 
Welsh, S. - Davis, C. - Shaw, A.: Young, Y.: Functional Foods and the Development of the Food Guide Pyramid. Nutrition Today. 1992. 27 (6) 12-23.

World Health Organization: Nutrition and Food Security. 2019. URL: https:// www.who.int/foodsafety/areas_work/ nutrition/en/ (Letöltés dátuma: 2019.06.02)

World Health Organization: Working together for health. The World Health Report 2006. URL: http://www.who. int/whr/2006/whro6_en.pdf (Letöltés dátuma: 2019.05.31)

European Consumer. In: Functional foods. II. Claims and evidence. (Szerk.: Buttriss, J. - Saltmarsh, M.). London, UK: The Royal Society of Chemistry. 2000. 25-34.

\section{JEGYZETEK $\nRightarrow$ NOTES}

